\title{
Cyanide intoxication as part of smoke inhalation - a review on diagnosis and treatment from the emergency perspective
}

\author{
Pia Lawson-Smith ${ }^{1 *}$, Erik C Jansen², Ole Hyldegaard ${ }^{1,2}$
}

\begin{abstract}
This paper reviews the current literature on smoke inhalation injuries with special attention to the effects of hydrogen cyanide. It is assumed that cyanide poisoning is still an overlooked diagnosis in fire victims. Treatment against cyanide poisoning in the emergency setting should be given based on the clinical diagnosis only. Oxygen in combination with a recommended antidote should be given immediately, the first to reduce cellular hypoxia and the second to eliminate cyanide. A specific antidote is hydroxycobalamin, which can be given iv. and has few side effects.
\end{abstract}

\section{The most common occurrence of cyanide poisoning}

Several reports have shown that persons admitted to hospital due to fire accidents may have been exposed to carbon monoxide $(\mathrm{CO})$ as well as cyanide $(\mathrm{CN})$ [1-3]. In fact, it has been reported that the most common source of $\mathrm{CN}$ poisoning in humans arise from exposure to fires [4]. In fires $\mathrm{CN}$ is developed when the temperature reaches $315^{\circ} \mathrm{C}\left(600^{\circ} \mathrm{F}\right)$ and is released from the toxic fumes in the gaseous form, i.e. hydrogen cyanide ( $\mathrm{HCN})$ which may then be inhaled by the victim [1]. HCN is developed from an incomplete combustion of any material containing nitrogen [5] such as plastic, vinyl, wool or silk [6]. It is worth noticing that when cotton burns it develops $130 \mu \mathrm{g} \mathrm{HCN} / \mathrm{g}$, paper $1100 \mu \mathrm{g} \mathrm{HCN} / \mathrm{g}$ and wool $6300 \mu \mathrm{g} \mathrm{HCN} / \mathrm{g}$. One has to be aware that $\mathrm{HCN}$ is still produced when the fire is only glowing embers [7].

\section{Symptoms of cyanide poisoning}

$\mathrm{HCN}$ is easily absorbed from all routes of exposure [8]. Since $\mathrm{CN}$ is a small lipid soluble molecule and mainly undissociated, distribution and penetration of $\mathrm{CN}$ into cells is rapid. $\mathrm{CN}$ can be distributed in the body within seconds and death can occur within seconds or minutes

\footnotetext{
* Correspondence: lawson_smith@dadlnet.dk

'Laboratory of Hyperbaric Medicine, Department of Anesthesia, Center of Head and Orthopaedics, University Hospital Rigshospitalet, Blegdamsvej,

Copenhagen, 2100, Denmark

Full list of author information is available at the end of the article
}

after a large dose $[9,10]$. Initially, the symptoms include a brief period of hyperpnoea, due to direct stimulation of the chemo receptors of the carotid and aortic bodies by $\mathrm{CN}$ [11]. $\mathrm{CN}$ also stimulates the nociceptors, leading to a brief sensation of dryness and burning in the nose and throat [12]. In milder cases of $\mathrm{CN}$ poisoning the symptoms are headache, nausea, vertigo, anxiety, altered mental status, tachypnea, hypertension and there may be an odour of bitter almonds in the patients expiration. In more severe cases the patient will have dyspnoea, bradycardia, hypotension and arrhythmia. In most severe cases the patients symptoms are unconsciousness, convulsions, cardiovascular collapse followed by shock, pulmonary oedema and death [6]. Death is due to respiratory arrest but the heart invariably outlasts respiration and may continue to beat for as long as 3-4 min. after the last gasp $[8,12]$.

Virtually all patients with severe, acute $\mathrm{CN}$ poisoning die immediately. Autopsy findings include petechial, subarachnoid or subdural haemorrhages [13]. As very few people survive severe $\mathrm{CN}$ poisoning, reports of late neurological sequelae are rare.

$\mathrm{CN}$ poisoning in mild degrees is recognized as a cause of permanent neurological disability, ranging from various extrapyramidal syndromes to post-anoxic vegetative states [14]. Most cases develop over many years. Both parkinsonian symptoms and a dystonia syndrome have been observed [15-18].

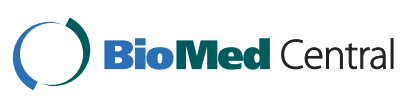




\section{Mechanism of toxicity of $\mathrm{CN}$}

The similarity between $\mathrm{CO}$ and $\mathrm{CN}$ is the ability to bind iron ions. However, where $\mathrm{CO}$ impairs the ability of erythrocytes to transfer oxygen, $\mathrm{CN}$ binds to erythrocytes but does not affect the oxygen transfer. Both $\mathrm{CO}$ and $\mathrm{CN}$ affect the mitochondria by binding to the enzyme cytochrome- $c$ oxidase a, a3 (CCO), the terminal enzyme complex of the respiratory chain in complex IV [10]. The active $\left(\mathrm{O}_{2}\right.$-binding $)$ site of $\mathrm{CCO}$ is binuclear, consisting of heme $a_{3}$ and $\mathrm{Cu}_{\mathrm{B}}$ [19]. CO binds to the reduced form of $\mathrm{CCO}$ and $\mathrm{CN}$ binds to either the reduced $\mathrm{CCO}$ heme $\left(\mathrm{Fe}^{2+}\right)$ or oxidized heme $\left(\mathrm{Cu}_{\mathrm{B}}{ }^{2+}\right)$ [20-22]. The primary effect of $\mathrm{CN}$ is a blocking of the mitochondrial respiration chain and the formation of intracellular adenosine triphosphate (ATP) [10]. The result is cytotoxic hypoxia caused by the inhibition of $\mathrm{CCO}$ by the high affinity of $\mathrm{CN}$ to heme $a_{3}$ of the enzyme. The effect is a structural change and a reduced activity of the enzyme and an increase in lactate production resulting in metabolic acidosis [23,24].

\section{Diagnosis}

$\mathrm{CN}$ poisoning seems to be an overlooked diagnosis in fire victims. In 1991, Baud showed that persons from fire accidents were poisoned by both $\mathrm{CN}$ and $\mathrm{CO}$ [25]. The diagnosis of $\mathrm{CN}$ poisoning presents a dilemma for firstresponse emergency personnel. Clinicians are often able to diagnose $\mathrm{CO}$ poisoning by either arterial- or venous blood sampling measuring carboxyhaemoglobin or by oximetry although the latter may be unreliable [26]. Diagnosing $\mathrm{CN}$ poisoning however, remains a challenge in the emergency setting. At the same time immediate treatment is of outmost importance. Given the fact that methods to detect and measure $\mathrm{CN}$ in blood are usually not readily available and that patients may often be exposed to both $\mathrm{CO}$ and $\mathrm{CN}$, clinicians have to rely on the presenting symptoms and the general clinical status of the patient. In patients hospitalised with a history of fire accident, combined with severe neurological symptoms such as reduced Glasgow Coma Scale (GCS) Scoring and either soot particles in the mouth or tracheal expectoration, is likely to be an indicator of concomitant $\mathrm{CN}$ poisoning [23]. Baud et al. found that the concentration of lactate increases proportionally with the amount of $\mathrm{CN}$ poisoning because of the metabolic acidosis [27].

Based on these observations and given the fact that whole blood $\mathrm{CN}$ measurements may not be available, the patient admitted to hospital after exposure to fire combined with smoke inhalation injuries, supplementary $\mathrm{CN}$ intoxication should be suspected if two or more of the following criteria are fulfilled:

1) Signs of neurological incapacitation such as altered mental status, unconsciousness and convulsions
2) Soot in the mouth or expectoration

3) Fire accident patents where arterial blood sampling reveal metabolic acidosis with a lactate above $8 \mathrm{mmol} / \mathrm{l}$ as the concentration of lactate increases proportional with the rate of $\mathrm{CN}$ poisoning. A lactate of $10 \mathrm{mmol} / \mathrm{l}$ is a sensitive and specific indicator of $\mathrm{CN}$ intoxication [23].

Currently, two methods of whole blood $\mathrm{CN}$ analysis dominates the literature:

One method is the Conway/microdiffusion method where test material is whole blood. $\mathrm{CN}$ is liberated from the blood into the gas phase and subsequently bound to hydroxycobalamin (OHCob) forming cyanocobalamin (CNCob). The concentration of CNCob can be read my means of a spectrophotometer [28]. Results are available within a 2 -h period.

The other method is isotope-dilution gas chromatography-mass spectrometry (ID GC/MS) that is an automated procedure where test material is whole blood. Samples are prepared and analysed within a 2-h period [29].

With the current available methods for the analysis of $\mathrm{CN}$ blood concentrations, one may conclude that in the clinical setting it takes hours before a result may be available for the treating doctor [30]. Furthermore, CN is an unstable molecule and has an elimination half-life of 1 hour in blood in vivo. Therefore determination of $\mathrm{CN}$ in blood requires rapid sampling and analysis $[25,27]$.

\section{Treatment}

The treatment of $\mathrm{CN}$ poisoning is aiming at basic life support including $100 \%$ oxygen, assisted ventilation if the patient is unconscious $(\mathrm{GCS}<8$ ) or the airway seems compromised, decontamination, correction of acidosis and blood pressure support [31,32] combined with the use of an antidote. Currently there are four types of antidotes. These include OHCob, sodium thiosulfate, dicobalt edetate and methaemoglobin forming antidotes. Initial evaluation of antidotal efficacy is based on correction of hypotension and lactic acidosis and the final outcome rests on the degree of permanent central nervous system injury [33]. The different antidotes shall be described briefly here below.

$\mathrm{OHCob}$ has a rapid onset of action as it dissolves into the different tissue compartments almost immediately when administered by infusion [34]. It has the advantage of not interfering with tissue oxygenation [35] and in both human and animal studies it has been shown to improve hemodynamic stability [34,36-38]. OHCob acts by covalent binding to $\mathrm{CN}$ and forms cyanocobalamin (CNCob) which is B12 vitamin $[39,40]$. CNCob is excreted through the kidneys [41]. Given iv. OHCob distributes to the erythrocytes and plasma cells and after 
30 minutes it reaches the cerebrospinal fluid [42]. Side effects are red colouring of skin and urine, urticarial eczema and seldom anaphylactic chock [32]. In a series of normal human volunteers given $5 \mathrm{~g}$ of OHCob iv. during 20 minutes, a mild, transient, self-limiting hypertension accompanied by reflex bradycardia has been reported [38]. OHCob must not delay any other basic life support such as securing of the airways, cardiovascular support or oxygen supply [31,32]. OHCob in blood interferes with $\mathrm{CO}$-oximetry measurements of $\mathrm{COHb}$, methemoglobin (MetHb), and $\mathrm{Hb}-\mathrm{O}_{2}$. This must be considered during $\mathrm{OHCob}$ treatment, particularly in smoke inhalation victims with concurrent $\mathrm{CO}$ exposure, because it may lead to potentially erroneous reported $\mathrm{COHb}$ levels. OHCob will cause an increase in measured $\mathrm{COHb}$ percentage values [43].

Sodium thiosulfate removes $\mathrm{CN}$ from the blood through the action of rhodanese [44]. Rhodanese is an enzyme located in the mitochondria mainly in the liver, kidney and skeletal muscles $[45,46]$. It adds a sulphur atom to $\mathrm{CN}$ and forms thiocyanate which is less toxic and excreted through the kidneys $[47,48]$. Sodium thiosulfate has limited distribution into the brain as well as limited penetration into the mitochondria, where the endogenous rhodanese is located [40,49]; accordingly sodium thiosulfate exerts its main effect in blood and plasma [50]. Sodium thiosulfate has a slow onset of action [6]. Less significant side effects such as nausea, vomiting, and injection site pain, irritation, and a burning sensation has been reported $[39,51]$. There is limited information available about the efficacy of sodium thiosulfate for treatment of $\mathrm{CN}$ poisoning [35]. No clinical trials of sodium thiosulfate are available, and efficacy has been extrapolated from case studies and series of acute $\mathrm{CN}$ poisoning.

Dicobalt EDTA is an efficient antidote with a high affinity to $\mathrm{CN}$ but it has restricted use. The mechanism of action is chelation of $\mathrm{CN}$ to form the much less toxic cobalt cyanide. Dicobalt EDTA has deleterious cardiovascular side effects and is often poorly tolerated. To mitigate these side effects intravenous glucose should be co administered during treatment. The side effects are enhanced if the patient is not $\mathrm{CN}$ poisoned so it should be used only in very severe cases where the diagnosis is certain $[32,35,40]$.

Amyl nitrite and sodium nitrite are methemoglobin forming antidotes, which are relatively contraindicated in smoke inhalation. Nitrite reduces blood $\mathrm{CN}$ by forming methemoglobin, to which $\mathrm{CN}$ binds with higher affinity than it does to CCO. Significant side effects such as vasodilatation and hypotension are seen during treatment. Induction of methemoglobin forming antidote treatment has the potential to impair the oxygen carrying capacity of haemoglobin [6]. In the smoke inhalation victim, with concomitant $\mathrm{COHgb}$ increase and possible pulmonary injury, there is an obvious added risk associated with methemoglobin formation [6].

\section{Adjunctive treatment of $\mathrm{CN}$ intoxication}

Hyperbaric oxygen therapy ( $\mathrm{HBO}$ ) is recommended by UHMS as an adjunct to the treatment of $\mathrm{CO}$ poisoning complicated by $\mathrm{CN}$ poisoning [52]. $\mathrm{HBO}$ has been shown to improve survival and improve tissue oxygenation in the clinical as well as in the experimental settings [53] and HBO is recommended especially when supportive measures and other $\mathrm{CN}$ antidotes fail [54-56]. Several studies have demonstrated a protective effect of HBO therapy in experimental ischemic brain injury, and many physiological and molecular mechanisms of $\mathrm{HBO}$ therapy-related neuroprotection have been identified [57]. Also HBO has been shown to reduce the risk of cognitive sequelae after acute $\mathrm{CO}$ poisoning when HBO is given within a 24-hour period [58]. Furthermore it has been shown that HBO increases the flexibility of red blood cells (thereby improving microcirculatory perfusion), reduces tissue oedema and preserves intracellular ATP [59-62]. The binding of CN to $\mathrm{CCO}$ is most often referred to as being irreversible $[23,32]$. However, recent evidence suggests that $\mathrm{CN}$ binding to $\mathrm{CCO}$ is reversible. Where $\mathrm{CN}$ binding to CCO appears to be independent of the oxygen tension, there seems to be a competition between $\mathrm{CN}$ and nitric oxide ( $\left.{ }^{\circ} \mathrm{NO}\right)$. High concentrations of ${ }^{\circ} \mathrm{NO}$ have been found to attenuate the inhibition of $\mathrm{CCO}$ induced by $\mathrm{CN}$ and $\mathrm{CO}[63,64]$. In keeping with this, HBO therapy, but not normobaric oxygen, has been shown to increase the bioavailability of "NO [65-69] which may show to be beneficial during $\mathrm{CN}$ poisoning. Whether $\mathrm{HBO}$ therapy holds any place in the treatment of acute $\mathrm{CN}$ poisoning when readily available is a matter of continued debate. In keeping with the above and the fact that patients from fires are both $\mathrm{CO}$ and $\mathrm{CN}$ poisoned we recommend $\mathrm{HBO}$ as well where safely available.

\section{Conclusion}

Treatment of suspected $\mathrm{CN}$ poisoning presents a dilemma for medical first-response emergency personnel, as clinicians are often unable to diagnose $\mathrm{CN}$ poisoning in the emergency setting. Immediate treatment is of outmost importance. In summary immediate treatment includes $100 \%$ oxygen, assisted ventilation if the patient is unconscious $(\mathrm{GCS}<8$ ) or the airway seems compromised, decontamination, correction of acidosis and blood pressure support [31,32]. Antidotes include OHCob, sodium thiosulfate, di-cobalt EDTA and methaemoglobin-inducers. Currently, there is no international agreement of which antidote is the preferred to use but $\mathrm{OHCob}$ and sodium thiosulfate seem to be 
among the most widely accepted antidotes. OHCob is an attractive antidote due to its rapid $\mathrm{CN}$ binding and its lack of serious side effects, even in the absence of $\mathrm{CN}$ intoxication. Accordingly this is the recommended antidote treatment in Denmark to known or suspected $\mathrm{CN}$ poisoning. In France $\mathrm{OHCob}$ is given prehospital by EMS personnel but not in Denmark, as the Health Ministry has not approved it for this use [70].

\author{
Author details \\ 'Laboratory of Hyperbaric Medicine, Department of Anesthesia, Center of \\ Head and Orthopaedics, University Hospital Rigshospitalet, Blegdamsvej, \\ Copenhagen, 2100, Denmark. ${ }^{2}$ Hyperbaric Unit, Department of Anesthesia, \\ Center of Head and Orthopaedics, University Hospital Rigshospitalet, \\ Copenhagen, 2100 Denmark.
}

\section{Authors' contributions}

PL-S drafted the manuscript. All authors read and approved the final manuscript.

\section{Competing interests}

The authors declare that they have no competing interests.

Received: 1 March 2010 Accepted: 3 March 2011

Published: 3 March 2011

\section{References}

1. Alarie Y: Toxicity of fire smoke. Crit Rev Toxicol 2002, 32:259-289.

2. Eckstein M, Maniscalco PM: Focus on smoke inhalation-the most common cause of acute cyanide poisoning. Prehosp Disaster Med 2006, 21:s49-s55.

3. Jones J, McMullen MJ, Dougherty J: Toxic smoke inhalation: cyanide poisoning in fire victims. Am J Emerg Med 1987, 5:317-321.

4. Walsh DW, Eckstein M: Hydrogen cyanide in fire smoke: an underappreciated threat. Emerg Med Serv 2004, 33:160-163.

5. Walsh DW, Eckstein M: Hydrogen cyanide in fire smoke: an underappreciated threat. Emerg Med Serv 2004, 33:160-163.

6. Gracia R, Shepherd G: Cyanide poisoning and its treatment. Pharmacotherapy 2004, 24:1358-1365.

7. Montgommery, et al: Comments on fire toxicity. 2008, 179-212, Comb. Tox.2.

8. Snodgrass WR: Clinical Toxicology. In Casarett and Doull's Toxicology - The basic science of poisons. Edited by: Klaassen CD, Amdur MO, Doull J. New York: McGraw-Hill; 1996:969-986.

9. Borowitz JL, Rathinavelu A, Kanthasamy A, Wilsbacher J, Isom GE: Accumulation of labeled cyanide in neuronal tissue. Toxicol Appl Pharmacol 1994, 129:80-85.

10. Baud FJ: Acute poisoning with carbon monoxide (CO) and cyanide (CN). Ther Umsch 2009, 66:387-397.

11. Smith RP: Toxic Responses of the blood. In Casarett and Doull's Toxicology - The basic science of poisons. Edited by: Klaassen CD, Amdur MO, Doull J. New York: McGraw-Hill; 1996:335-354.

12. Eyer P: Gasses. In Toxicology. Edited by: Marquardt H, Schäfer SG, McClellan R, Welsch F. San Diego, CA: Academic Press; 1999:805-832.

13. Brierley JB, Graham Dl: Hypoxia and vascular disorders of the central nervous system. Greenfield's neuropathology London: Arnold; 1984, 125-207.

14. Rachinger J, Fellner FA, Stieglbauer K, Trenkler J: MR changes after acute cyanide intoxication. AJNR Am J Neuroradiol 2002, 23:1398-1401.

15. Finelli PF: Case report. Changes in the basal ganglia following cyanide poisoning. J Comput Assist Tomogr 1981, 5:755-756.

16. Messing B: Extrapyramidal disturbances after cyanide poisoning (first MRT-investigation of the brain). J Neural Transm Supp/ 1991, 33:141-147.

17. Rosenberg NL, Myers JA, Martin WR: Cyanide-induced parkinsonism: clinical, MRI, and 6-fluorodopa PET studies. Neurology 1989, 39:142-144.

18. Uitti RJ, Rajput AH, Ashenhurst EM, Rozdilsky B: Cyanide-induced parkinsonism: a clinicopathologic report. Neurology 1985, 35:921-925.
19. Yoshikawa S, Shinzawa-Itoh K, Tsukihara T: Crystal structure of bovine heart cytochrome c oxidase at $2.8 \mathrm{~A}$ resolution. J Bioenerg Biomembr 1998, 30:7-14.

20. Piantadosi CA, Zhang J, Demchenko IT: Production of hydroxyl radical in the hippocampus after CO hypoxia or hypoxic hypoxia in the rat. Free Radic Biol Med 1997, 22:725-732.

21. Sarti P, Giuffre A, Barone MC, Forte E, Mastronicola D, Brunori M: Nitric oxide and cytochrome oxidase: reaction mechanisms from the enzyme to the cell. Free Radic Biol Med 2003, 34:509-520.

22. van Buuren KJ, Nicholis P, van Buuren BF: Biochemical and biophysical studies on cytochrome aa 3. VI. Reaction of cyanide with oxidized and reduced enzyme. Biochim Biophys Acta 1972, 256:258-276.

23. Baud FJ: Cyanide: critical issues in diagnosis and treatment. Hum Exp Toxicol 2007, 26:191-201.

24. Beasley DM, Glass WI: Cyanide poisoning: pathophysiology and treatment recommendations. Occup Med (Lond) 1998, 48:427-431.

25. Baud FJ, Barriot P, Toffis V, Riou B, Vicaut E, Lecarpentier Y, Bourdon R, Astier A, Bismuth C: Elevated blood cyanide concentrations in victims of smoke inhalation. N Engl J Med 1991, 325:1761-1766.

26. Weaver L, Deru K, Churchill S, Cooney D: False positive Rate of Carbon Monoxide Saturation By Pulse Oximetry Of Emergency Department Patients [abstract]. Undersea Hyperb Med 2010, 76.

27. Baud FJ, Borron SW, Megarbane B, Trout H, Lapostolle F, Vicaut E, Debray $M$, Bismuth C: Value of lactic acidosis in the assessment of the severity of acute cyanide poisoning. Crit Care Med 2002, 30:2044-2050.

28. Laforge M, Buneaux F, Houeto P, Bourgeois F, Bourdon R, Levillain P: A rapid spectrophotometric blood cyanide determination applicable to emergency toxicology. J Anal Toxicol 1994, 18:173-175.

29. Murphy KE, Schantz MM, Butler TA, Benner BA Jr, Wood LJ, Turk GC Determination of cyanide in blood by isotope-dilution gas chromatography-mass spectrometry. Clin Chem 2006, 52:458-467.

30. Dart RC, Bogdan GM: Acute cyanide poisoning: causes, consequences, recognition and management. Frontline First Responder 2004, 2:19-22.

31. European Medicines Agency: Hydroxocobalamin. London, European Medicines Agency; 2007.

32. Megarbane B, Delahaye A, Goldgran-Toledano D, Baud FJ: Antidotal treatment of cyanide poisoning. J Chin Med Assoc 2003, 66:193-203.

33. Borron SW, Baud FJ: Acute cyanide poisoning: clinical spectrum, diagnosis, and treatment. Arh Hig Rada Toksikol 1996, 47:307-322

34. Hall AH, Saiers J, Baud F: Which cyanide antidote? Crit Rev Toxicol 2009, 39:541-552.

35. Meredith TJ, Jacobsen D, Haines JA, Berger JC, van Heijst ANP: IPCS/CEC Evaluation of Antidotes Series. Cambrigde, UK: Cambridge University Press; 20092.

36. Borron SW, Stonerook M, Reid F: Efficacy of hydroxocobalamin for the treatment of acute cyanide poisoning in adult beagle dogs. Clin Toxicol (Phila) 2006, 44(Suppl 1):5-15.

37. Borron SW, Baud FJ, Megarbane B, Bismuth C: Hydroxocobalamin for severe acute cyanide poisoning by ingestion or inhalation. Am J Emerg Med 2007, 25:551-558.

38. Fortin JL, Waroux S, Giocanti JP, Capellier G, Ruttimann M, Kowalski JJ: Hydroxocobalamin for Poisoning Caused by Ingestion of Potassium Cyanide: A Case Study. J Emerg Med 2008, 39:320-324.

39. Forsyth JC, Mueller PD, Becker CE, Osterloh J, Benowitz NL, Rumack BH, Hall AH: Hydroxocobalamin as a cyanide antidote: safety, efficacy and pharmacokinetics in heavily smoking normal volunteers. J Toxicol Clin Toxicol 1993, 31:277-294.

40. Way JL: Cyanide intoxication and its mechanism of antagonism. Annu Rev Pharmacol Toxicol 1984, 24:451-481.

41. Hall AH, Rumack BH: Hydroxycobalamin/sodium thiosulfate as a cyanide antidote. J Emerg Med 1987, 5:115-121.

42. Van den Berg MP, Merkus P, Romeijn SG, Verhoef JC, Merkus FW: Hydroxocobalamin uptake into the cerebrospinal fluid after nasal and intravenous delivery in rats and humans. J Drug Target 2003, 11:325-331.

43. Lee J, Mukai D, Kreuter K, Mahon S, Tromberg B, Brenner M: Potential interference by hydroxocobalamin on cooximetry hemoglobin measurements during cyanide and smoke inhalation treatments. Ann Emerg Med 2007, 49:802-805.

44. Hall AH, Rumack BH: Clinical toxicology of cyanide. Ann Emerg Med 1986 15:1067-1074. 
45. Bhatt KR, Daniel PM, Pratt OE: The release of cobalamin from muscles after haemorrhage. J Physiol 1982, 324:17P

46. LUDEWIG S, CHANUTIN A: Distribution of enzymes in the livers of control and x-irradiated rats. Arch Biochem 1950, 29:441-445.

47. Piantadosi CA, Sylvia AL: Cerebral cytochrome a,a3 inhibition by cyanide in bloodless rats. Toxicology 1984, 33:67-79.

48. Morocco AP: Cyanides. Crit Care Clin 2005, 21:691-705, vi.

49. Baskin SI, Horowitz AM, Nealley EW: The antidotal action of sodium nitrite and sodium thiosulfate against cyanide poisoning. I Clin Pharmacol 1992, 32:368-375.

50. Beasley DM, Glass WI: Cyanide poisoning: pathophysiology and treatment recommendations. Occup Med (Lond) 1998, 48:427-431.

51. Morocco AP: Cyanides. Crit Care Clin 2005, 21:691-705, vi.

52. UHMS: Hyperbaric Oxygen Therapy Indications Book. The Undersea and Hyperbaric Medical Society; 2008.

53. Davis FM, Ewer T: Acute cyanide poisoning: case report of the use of hyperbaric oxygen. J Hyper Med 1988, 3:103-106.

54. Hall AH, Rumack BH: Clinical toxicology of cyanide. Ann Emerg Med 1986, 15:1067-1074.

55. Thom SR, Keim LW: Carbon monoxide poisoning: a review epidemiology, pathophysiology, clinical findings, and treatment options including hyperbaric oxygen therapy. J Toxicol Clin Toxicol 1989, 27:141-156.

56. Way JL, End E, Sheehy MH, De MP, Feitknecht UF, Bachand R, Gibbon SL, Burrows GE: Effect of oxygen on cyanide intoxication. IV. Hyperbaric oxygen. Toxicol Appl Pharmacol 1972, 22:415-421.

57. Matchett GA, Martin RD, Zhang JH: Hyperbaric oxygen therapy and cerebral ischemia: neuroprotective mechanisms. Neurol Res 2009, 31:114-121.

58. Weaver LK, Hopkins RO, Chan KJ, Churchill S, Elliott CG, Clemmer TP, Orme JF Jr, Thomas FO, Morris AH: Hyperbaric oxygen for acute carbon monoxide poisoning. N Engl J Med 2002, 347:1057-1067.

59. LaVan FB, Hunt TK: Oxygen and wound healing. Clin Plast Surg 1990, 17:463-472.

60. Nylander G, Nordstrom H, Eriksson E: Effects of hyperbaric oxygen on oedema formation after a scald burn. Burns Ind Therm Inj 1984, 10:193-196.

61. Thom SR: Dehydrogenase conversion to oxidase and lipid peroxidation in brain after carbon monoxide poisoning. J Appl Physiol 1992, 73:1584-1589

62. van der Kleij AJ, Vink H, Henny CP, Bakker DJ, Spaan JA: Red blood cell velocity in nailfold capillaries during hyperbaric oxygenation. Adv Exp Med Biol 1994, 345:175-180.

63. Pearce $L L$, Bominaar EL, Hill BC, Peterson J: Reversal of cyanide inhibition of cytochrome coxidase by the auxiliary substrate nitric oxide: an endogenous antidote to cyanide poisoning? I Biol Chem 2003, 278:52139-52145.

64. Pearce LL, Lopez ME, Martinez-Bosch S, Peterson J: Antagonism of nitric oxide toward the inhibition of cytochrome $\mathrm{c}$ oxidase by carbon monoxide and cyanide. Chem Res Toxicol 2008, 21:2073-2081.

65. Allen BW, Demchenko IT, Piantadosi CA: Two faces of nitric oxide: implications for cellular mechanisms of oxygen toxicity. J Appl Physiol 2009, 106:662-667.

66. Ohgami Y, Chung E, Shirachi DY, Quock RM: The effect of hyperbaric oxygen on regional brain and spinal cord levels of nitric oxide metabolites in rat. Brain Res Bull 2008, 75:668-673.

67. Thom SR, Bhopale V, Fisher D, Manevich Y, Huang PL, Buerk DG: Stimulation of nitric oxide synthase in cerebral cortex due to elevated partial pressures of oxygen: an oxidative stress response. J Neurobiol 2002, 51:85-100.

68. Thom SR, Fisher D, Zhang J, Bhopale VM, Ohnishi ST, Kotake Y, Ohnishi T, Buerk DG: Stimulation of perivascular nitric oxide synthesis by oxygen. Am J Physiol Heart Circ Physiol 2003, 284:H1230-H1239.

69. Xu X, Wang Z, Li Q, Xiao X, Lian Q, Xu W, Sun X, Tao H, Li R: Endothelial nitric oxide synthase expression is progressively increased in primary cerebral microvascular endothelial cells during hyperbaric oxygen exposure. Oxid Med Cell Longev 2009, 2:7-13.

70. Fortin JL, Giocanti JP, Ruttimann M, Kowalski Jj: Prehospital administration of hydroxocobalamin for smoke inhalation-associated cyanide poisoning: 8 years of experience in the Paris Fire Brigade. Clin Toxicol (Phila) 2006, 44(Suppl 1):37-44. doi:10.1186/1757-7241-19-14

Cite this article as: Lawson-Smith et al: Cyanide intoxication as part of smoke inhalation - a review on diagnosis and treatment from the emergency perspective. Scandinavian Journal of Trauma, Resuscitation and Emergency Medicine 2011 19:14.

\section{Submit your next manuscript to BioMed Central and take full advantage of:}

- Convenient online submission

- Thorough peer review

- No space constraints or color figure charges

- Immediate publication on acceptance

- Inclusion in PubMed, CAS, Scopus and Google Scholar

- Research which is freely available for redistribution

Submit your manuscript at www.biomedcentral.com/submit
Ciomed Central 